\title{
BULLYING AMONG PRIMARY SCHOOL STUDENTS: PARENTAL INVOLVEMENT AND TEACHERS' PERCEPTIONS
}

\author{
By \\ El-Maghawry HA and El-Shafei D \\ Department of Community, Environmental and Occupational Medicine, Faculty of Medicine, Zagazig \\ University, Egypt \\ Corresponding author: El-MaghawryHA.Email: HAMaghawry@medicine.zu.edu.eg
}

Submit Date: 2020-10-24

Revise Date: 2020-11-22

Accept Date: 2020-11-23

DOI: $10.21608 /$ ejom.2020.47309.1216

Authors' contribution: Authors contributed equally to this work.

\begin{abstract}
Introduction: Bullying is a form of violence that endangers well-being of children, youth and adults. It results from the interaction of multiple factors related to individual characteristics, relationships with peers, adults, and school or community expectations. Bullying in schools is a major public health concern which recently gained considerable interest in the Arab world. The most serious consequence of school bullying is reduction in academic performance due to the perception and avoidance of school as an insecure environment. Aim of work: This study was performed in order (1) To determine the prevalence of school bullying behavior among governmental primary school students in Egypt, (2) To evaluate whether parental involvement is associated with peer victimization among students, (3) To understand how primary school teachers perceive bullying and how they act in response to it. Materials and Methods: A cross-sectional study of an Egyptian nationally representative sample of governmental primary school students was done ( 809 students). Main teachers of the classes were also included (83 teachers). Different types of questionnaire were used including: socio-demographic characteristics, the Arabic version of The Peer Interactions in Primary School Questionnaire (PIPSQ) to collect information on both direct and indirect bullying, parental involvement assessment in the students' lives by using the Arabic version of Global School Student Health Survey tool and finally, teachers' perception of school bullying. Results: Most of the students were in the age group 11 years old or over. More than half of them were both bullies and bullied others. Parental involvement was linked to decreased likelihood of victimization. Most teachers agreed that the school plays an important role in reducing the occurrence of bullying and agreed that topics about bullying prevention must be part of the elementary school curriculum. Conclusion:
\end{abstract}


Involvement of the parents is associated with a decreased risk of victimization. Most teachers had misperceptions about identification of bullying and its parameters.

Key words: Bullying, Egypt, Parental involvement, Primary school and Teachers'perceptions

\section{Introduction}

Bullying is a form of violence that endangers well-being of children, youth and adults (Markkanen et al., 2019). A person is a victim of bullying when he or she is exposed by one or more individual repeatedly over time to any unwanted aggressive behavior(s) and is unable to defend him or herself, excluding situations in which two individuals with equal physical and psychological strength are fighting (Olweus, 1994).

The 4 main components of school bullying are the bully (bullying behavior perpetrator); the victim (bullying behavior recipient); the bully/ victim (victim and perpetrator); and the bystander (bullying behavior witness) (Olweus, 1994). School bullying can include peer victimization in which a student or group of students bullies an individual peer or group of peers; teacher-on-student bullying is when a teacher bullies a student; and studenton-teacher bullying in which a student bullies a teacher (Markkanen et al., 2019). The most serious consequence of school bullying is deterioration in academic performance due to the perception and avoidance of school as an unsafe place, presence of low selfesteem and isolation that is carried to adulthood (Kazarian and Ammar, 2013). Family socioeconomic dynamics and relationships play a key role in behavior of children towards their peers in bullying-victimization. High parental involvement and emotional support, and good parent-child communication and supervision are considered to protect against victimization and decrease emotional disturbance and behavioral issues in the bullied child while maladaptive parenting, abuse and neglect were predictive of victimization (Lester et al., 2017). Teacher perceptions of student bullying constitute an important first step in reducing this danger (Jungert et al., 2016). Teachers are seen by parents as protectors, a source of support and the first line of defense in the identification of bullying as they play a central role in prevention of bullying and intervention in schools, so it is important to understand how teachers perceive bullying (Garandeau et al., 2016). Bullying in schools is an 
important public health issue which has recently gained considerable attention in the Arab world. While bullying in middle and high schools has been thoroughly studied, little is known about the characteristics of bullying among elementary school children (Kevorkian et al., 2016).

Unfortunately, in Egypt, bullying is an under-researched field although it can occur among school children at a very young age and can grow worse over the years. Just few studies on parental involvement and the perceptions of bullying by teachers in elementary school have been carried out.

\section{Aim of work}

This study was performed in order to (1) determine the prevalence of school bullying behavior among governmental primary school students in Egypt, (2) evaluate whether parental involvement is associated with peer victimization among students (3) understand how primary school teachers perceive bullying and what they act in response to it.

\section{Materials and Methods}

Study design: It is a cross sectional study.

Place and duration of the study: El Sharkia and El Beheira Governorates in the academic year 2019-2020.

\section{Study sample:}

Students: An Egyptian nationally representative sample of governmental primary school students was selected by a multistage cluster sample design. First, two governorates (El Sharkia and El Beheira Governorates) were selected randomly from a list of all country governorates. One district was selected randomly from a list of all districts in each selected governorate. Then two governmental primary schools were randomly selected from a list of schools in each district, one from urban area and the second was from rural area. Lastly, according to proportional allocation of number of students registered in governmental primary schools in the academic year 2017-2018 in El Sharkia and El Beheira Governorates (1.1: 1), the sample was 424 students from El Sharkia Governorate and 385 students from El Beheira Governorate (4 classes were randomly selected for inclusion in the study from within classrooms with a total of 16 classes, about 50 students in each class) starting from grade three to grade six to ensure better understanding and cooperation (one class in each grade is selected randomly). All random selection was done by using 
simple random sampling technique. The sample size was calculated using Version 2.3.1. of the Epi Info software program (Sample size calculation, 2017 ) at $95 \%$ confidence interval and population size (number of students enrolled in all governmental primary schools in Egypt in the academic year 2017-2018 was 6777790 students (CAPMAS, 2018), assuming problem frequency of $60.3 \%$ (Abdirahman et al., 2013) and a margin of error 5\%, the minimum sample size was 368 participants. Using a design effect of 2 (Dean et al., 2013) to compensate for the error of the estimate encountered using cluster sampling instead of simple random sampling and adding 10\% (73 students) to compensate for potential non-response, the final total sample size was estimated to be 809 students.

Teachers: Main teachers of the 16 classes from the four schools were also included in the study (total 83 teachers) to assess teachers' perceptions of bullying behaviour and its risk factors among students.

\section{Study methods:}

\section{1- A questionnaire including socio-} demographic characteristics: including age, sex of students and teachers.
2- The Arabic version of The Peer Interactions in Primary School Questionnaire (PIPSQ): it is used in school age children to collect information on both direct and indirect bullying (bully scale contains 10 items) and victimization (victim scale contains 12 items). Each item describes a different behavior, and the respondent is asked to detect the frequency with which this behavior occurred even with any response greater than or equal to one day over the previous month (Galal et al., 2019). The investigator first gave a bullying explanation (Olweus, 1994). The PIPSQ was designed to be understood by third-grade students by using the Flesch-Kincaid standard. For each question, students choose one of three answer categories (never, often, a lot) and then numeric values for each response category $(0,1$, and 2) are added to give a scaled score (Hussein, 2010).

3- Parental involvement assessment was studied by using the Arabic version of Global School Student Health Survey tool: For students who have been identified as bullying victims, questions were used to 
measure parental involvement in the lives of their children: 1) "How often did your parents or guardians monitor if your homework had been done during the past month?", 2) "How often did your parents consider your issues and concerns much of the time, or always during the past month?" and 3) "How often did your parents or guardians know what you were doing with your free time during the past month?". Possible answers were: never, seldom, sometimes, most of the time and always. Each variable had been recoded into dichotomous variables where never, rarely and sometimes represent low levels of parental involvement and responses of most of the time and always represent high levels of parental involvement (GSHS, 2011).

4- Teachers' perception of school bullying tool: teachers of the selected classes were invited to fill a modified 7-questions Arabic edition of an 18-questions questionnaire (Farahat, 2019) that were divided into three sections to determine how school teachers perceive bullying and what they are doing in response to it. The first section covered bullying identification (teachers' perceptions and general knowledge about bullying). The second section covered bullying intervention, which measures teachers' behaviors and their willingness to intervene in bullying situations. The third section contained questions about bullying prevention. The scoring was calculated according to a Likert scale of three-point (Yes, I don't know, NO).

\section{Consent}

An informed consent was obtained from each participant (students, teachers) prior to data collection which addresses the confidentiality of data collected and assuring that participation in the study is completely voluntary.

\section{Ethical approval}

Prior to implementation of the study, approval was obtained from the Institutional Review Board (IRB) for Medical Research Ethics, Zagazig University, Faculty of Medicine (ZUIRB 5893) and official approval was obtained from the mentioned schools of the two governorates. The researchers explained the research and its objectives to the principals of schools.

\section{Data management}

It was conducted using the software 
SPSS (Statistical Package for the Social Sciences) version 20. The qualitative data were summarized using frequency and percentages. Statistical differences between qualitative variable groups were tested using the chi-squared test.
Odd's ratio was used to analyze whether parental involvement was an indicator for a student being a victim of bullying. Statistical significance level was set at $5 \%(\mathrm{p}<0.05)$.

\section{Results}

Table 1: Demographic data of the study participants.

\begin{tabular}{|c|c|c|c|}
\hline Students & $\begin{array}{l}\text { El Sharkia Governorate } \\
\qquad \begin{array}{c}(\mathrm{No}=424) \\
\text { No. }(\%)\end{array}\end{array}$ & $\begin{array}{l}\text { El Beheira Governorate } \\
\qquad \begin{array}{c}\text { No }=385) \\
\text { No. }(\%)\end{array}\end{array}$ & $\begin{array}{c}\text { Total } \\
(\text { No }=809) \\
\text { No. }(\%)\end{array}$ \\
\hline \multicolumn{4}{|l|}{ Sex: } \\
\hline Female & $208(49.1)$ & $190(49.4)$ & $398(49.1)$ \\
\hline Male & $216(50.9)$ & 195 (50.6) & $411(50.9)$ \\
\hline \multicolumn{4}{|c|}{ Age group (years): } \\
\hline$\leq 8$ & $50(11.7)$ & $45(11.7)$ & 95 (11.7) \\
\hline 9 & $81(19.2)$ & $71(18.5)$ & $152(18.7)$ \\
\hline 10 & $93(21.9)$ & 177 (45.9) & $270(33.4)$ \\
\hline$\geq 11$ & $200(47.2)$ & 92 (23.9) & $292(36.2)$ \\
\hline Teachers & $\begin{array}{l}\text { EI Sharkia Governorate } \\
\qquad \begin{array}{c}(\text { No }=46) \\
\text { No. }(\%)\end{array}\end{array}$ & $\begin{array}{l}\text { El Beheira Governorate } \\
\qquad \begin{array}{c}(\text { No }=37) \\
\text { No. }(\%)\end{array}\end{array}$ & $\begin{array}{c}\text { Total } \\
(\text { No }=83) \\
\text { No. }(\%)\end{array}$ \\
\hline \multicolumn{4}{|l|}{ Sex: } \\
\hline Female & $33(71.8)$ & 27 (72.9) & $60(72.2)$ \\
\hline Male & $13(28.2)$ & $10(27.1)$ & $23(27.8)$ \\
\hline \multicolumn{4}{|c|}{ Age group (years): } \\
\hline$\leq 23-30$ & $13(28.3)$ & $11(29.8)$ & $24(28.9)$ \\
\hline$>30$ & $33(71.7)$ & $26(70.2)$ & $59(71.1)$ \\
\hline
\end{tabular}

The 809 students (398 girls, and 411 boys) completed the questionnaires. The Majority of students were in the 11 years old or more group. About three quarters of the teachers were female (72.2\%) and $71.1 \%$ were above 30 years old (Table1). 
Fig. 1: Bullying behavior percentages among governmental primary school students in Egypt.

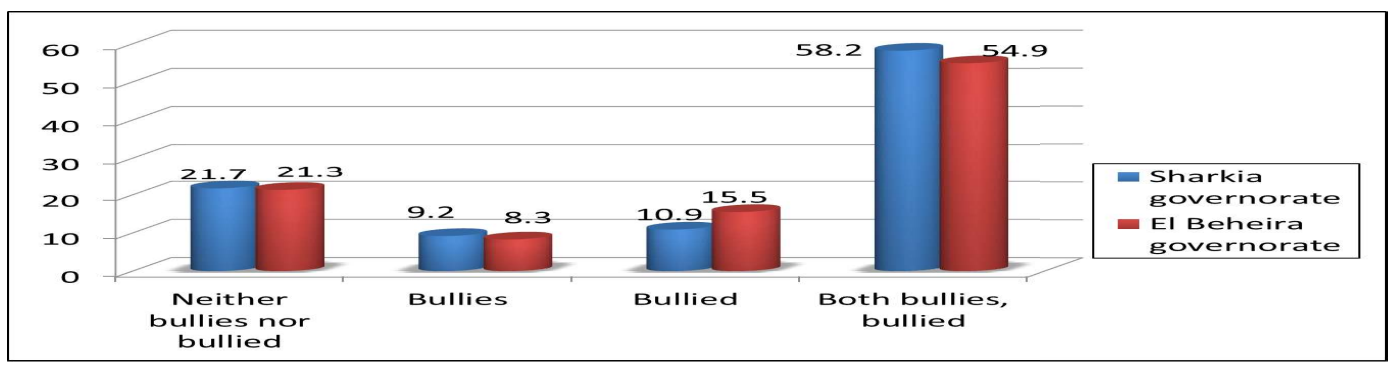

Fig 1 showed that among the 809 students, more than one half of students both bullies and were bullied

Table 2: Percentage of student bullies, victims, and bullies/victims by age and gender among the participants.

\begin{tabular}{lcccc}
\hline \multicolumn{1}{c}{ Characteristics } & $\begin{array}{c}\text { Neither bullied } \\
\text { nor bully } \\
\text { No. (\%) }\end{array}$ & $\begin{array}{c}\text { Bullies } \\
\text { No.(\%) }\end{array}$ & $\begin{array}{c}\text { Bullied (victim) } \\
\text { No. (\%) }\end{array}$ & $\begin{array}{c}\text { Both bullied and } \\
\text { bully } \\
\text { No. (\%) }\end{array}$ \\
\hline Total & $174(21.5)$ & $71(8.9)$ & $106(13.1)$ & $458(56.5)$ \\
\hline Sex: & & & & \\
Female & $87(50.0)$ & $32(45.1)$ & $51(48.1)$ & $228(49.7)$ \\
Male & $87(50.0)$ & $39(54.9)$ & $55(51.9)$ & $230(50.3)$ \\
$\chi 2$ test pvalue & 0.8 & 0.4 & 0.5 & 0.7 \\
\hline Age group (years): & & & & \\
$\leq 8$ & $20(11.5)$ & $8(11.2)$ & $12(11.3)$ & $55(12.1)$ \\
9 & $32(18.4)$ & $13(18.3)$ & $19(17.9)$ & $88(19.2)$ \\
10 & $58(33.3)$ & $24(33.8)$ & $35(33.1)$ & $153(33.4)$ \\
$\geq 11$ & $64(36.8)$ & $26(36.7)$ & $40(37.7)$ & $162(35.3)$ \\
$\chi 2$ test $\boldsymbol{p}$ value & 0.9 & 0.9 & 0.8 & 0.9 \\
\hline
\end{tabular}

Table 2 showed that the rate of victimization increased with age. However, this difference was not statistically significant $(p>0.05)$ 
Table 3: Number of bullied students having parental involvement by age and sex and association between bullying and parental involvement, adjusted for sex and age.

\begin{tabular}{|c|c|c|}
\hline Characteristics & $\begin{array}{c}\text { Total } \\
\text { No. }(\%)\end{array}$ & $\begin{array}{l}\chi 2 \text { test } \\
\text { p value }\end{array}$ \\
\hline Total Bullied (victims) & $106(13.1)$ & \\
\hline $\begin{array}{l}\text { Parents monitor homework most of the time or always } \\
\text { - Females } \\
\text { - Males }\end{array}$ & $\begin{array}{l}41(38.6) \\
21(51.2) \\
20(48.8)\end{array}$ & 0.6 \\
\hline $\begin{array}{l}\text { Age } \\
\quad \leq 8 \text { years } \\
\quad 9 \text { years } \\
\quad 10 \text { years } \\
\quad \geq 11 \text { years } \\
\end{array}$ & $\begin{array}{l}14(34.2) \\
13(31.7) \\
8(19.5) \\
6(14.6) \\
\end{array}$ & 0.2 \\
\hline $\begin{array}{l}\text { Parents consider their issues and concerns much of the time, or always } \\
\text { - Females } \\
\text { - Males }\end{array}$ & $\begin{array}{l}30(28.4) \\
13(43.3) \\
17(56.7)\end{array}$ & 0.5 \\
\hline $\begin{array}{l}\text { Age } \\
-\quad \leq 8 \text { years } \\
\text { - } 9 \text { years } \\
\text { - } 10 \text { years } \\
\quad \geq 11 \text { years }\end{array}$ & $\begin{array}{l}11(36.7) \\
9(30.0) \\
6(20.0) \\
4(13.3)\end{array}$ & 0.9 \\
\hline $\begin{array}{l}\text { Parents know how they spend their free time most of the time or always } \\
\text { - Females } \\
\text { - Males }\end{array}$ & $\begin{array}{l}47(44.3) \\
26(55.3) \\
21(44.7)\end{array}$ & 0.1 \\
\hline $\begin{array}{l}\text { Age } \\
\text { - } \quad \leq 8 \text { years } \\
\text { - } 9 \text { years } \\
10 \text { years } \\
\quad \geq 11 \text { years }\end{array}$ & $\begin{array}{l}13(27.7) \\
16(34.1) \\
11(23.4) \\
7(14.8)\end{array}$ & 0.1 \\
\hline $\begin{array}{l}\text { Association between bullying and parental involvement, adjusted for } \\
\text { sex and age (OR (95\% CI)): } \\
\text { - Bullying and parental homework checks } \\
\text { - Bullying and parental understanding } \\
\text { - Bullying and parental knowledge of free time }\end{array}$ & $\begin{array}{l}9.9(0.3895- \\
0.8094)^{*} \\
26.3(0.2489- \\
0.5533) * \\
4.2(0.4815- \\
0.984) *\end{array}$ & \\
\hline
\end{tabular}

*: statistically significant 
Table 3 showed that $38.6 \%$ of the bullied students reported parental involvement by monitoring homework most of the time or always (not statistically significant). Generally speaking, senior children showed reduced homework checking by parents, lesser parental understanding and less free-time guardians' supervision than younger students (statistically significant). Parental involvement has been linked to a reduced probability of bullying in Egypt.

Table 4: Perception about Bullying identification, intervention and prevention among the studied teachers.

\begin{tabular}{|c|c|c|c|}
\hline \multirow[b]{2}{*}{ Teachers' perception } & \multicolumn{3}{|c|}{$(\mathrm{No}=83)$} \\
\hline & $\begin{array}{c}\text { Yes } \\
\text { No. }(\%)\end{array}$ & $\begin{array}{l}\text { I don't } \\
\text { know } \\
\text { No. }(\%)\end{array}$ & $\begin{array}{c}\text { NO } \\
\text { No. }(\%)\end{array}$ \\
\hline - $\quad$ Bullying identification: & & & \\
\hline $\begin{array}{l}\text { 1. I have witnessed or received a report of multiple } \\
\text { incidents of bullying at the school during the last month. }\end{array}$ & $31(37.3)$ & $5(6.1)$ & $47(56.6)$ \\
\hline $\begin{array}{l}\text { 2. I find it hard to differentiate between bullying and } \\
\text { playful teasing. }\end{array}$ & $28(33.7)$ & $4(4.9)$ & $51(61.4)$ \\
\hline $\begin{array}{l}\text { 3. The school plays an important role in reducing the } \\
\text { occurrence of bullying. }\end{array}$ & $81(97.6)$ & $1(1.2)$ & $1(1.2)$ \\
\hline $\begin{array}{l}\text { 4. Bullying can have a serious impact on children }>\mathrm{S} \\
\text { development. }\end{array}$ & $82(98.8)$ & $1(1.2)$ & $0(0.0)$ \\
\hline $\begin{array}{l}\text { Bullying intervention: } \\
\text { 5. I believe that female teachers are more responsive to } \\
\text { bullying than male teachers }\end{array}$ & $79(95.2)$ & $1(1.2)$ & $3(3.6)$ \\
\hline $\begin{array}{l}\text { Bullying prevention } \\
\text { 6. Topics about bullying prevention should be part of the } \\
\text { elementary school curriculum }\end{array}$ & $82(98.8)$ & $1(1.2)$ & $0(0.0)$ \\
\hline $\begin{array}{l}\text { 7. I don't believe it is essential to include teachers in the } \\
\text { bullying prevention programs, focusing only on students } \\
\text { should be enough. }\end{array}$ & $4(4.8)$ & $1(1.2)$ & $78(94.0)$ \\
\hline
\end{tabular}

More than one half of teachers $(56.6 \%)$ disagreed that they had received or witnessed reports about bullying incidents during the last month in school (Table 4). 


\section{Discussion}

School bullying is a serious problem that should be dealt with at the international and the local levels. School bullying takes place in a variety of Arab countries, including Egypt (Kazarian and Ammar, 2013).

In the current study, we compare bullying rates, parental involvement and study teachers' perception in Egypt that could have relevant effect for schools and institutions. In Governorates (El Sharkia and El Beheira Governorates), proportion of male and female participants was fairly equal. The vast majority of the students were in the age category 11 years old or more (Table 1 ). Among the 809 students, more than one half of students was both bullies and bullied and $13.1 \%$ of the students in the two governorates reported being bullied (victims) in the past month (Fig. 1 and Table 2).

The results of the current study were higher than the prevalence of bullying victims reported by Khafagy (2000) in his study on the prevalence of bullying behavior and its association with healthrelated symptoms among preparatory school students in Mansoura city (10.5\%).

However, the prevalence of bullying in the present study is lower than the prevalence of bullying reported in Egypt in 2013 (60.3\%) in a study done by Abdirahman et al. on countries that participated in the GSHS (Global School-based Student Health Survey).

Issues about school-based violence in Egypt have been reported by Egypt's National Center for Social and Criminal Research, which in a recent research about students in primary and secondary schools; found that $69 \%$ of students reported being bullied or experiencing aggression from other students (Abdirahman et al., 2013).

Several researchers from around the world on disparities in bullying by sex have reported higher incidence of victimization in males than in females (Menesini and Salmivalli, 2017), (Haraldstad et al., 2019). The present study showed that boys reported being more bullied than girls $(51.9 \%$ vs. $48.1 \%$ ) (Table 2). This may be due to more overt bullying by boys such as verbal and physical violence while girls face indirect bullying such as social exclusion or spreading lies; in addition indirect bullying may be less likely to be identified. That is in line with the GSHS analysis, which mentioned that boys in North Africa were more likely 
than girls to be victimized (Gong et al., 2020). In the present study, the recorded victimization rate increased with age (Table 2). These findings were consistent with those of Rubens et al. (2019) who reported that bullying and school aggression increased with age These results do not agree with previous researches from other parts of the world, which almost universally reported that bullying rates in early adolescents decline with age (Fleming and Jacobsen, 2010).

Parental involvement in the current study was reported to be lower among children in the age group of 11 years and older (Table 3). Parental involvement identified was almost not affected by the child's gender. However, the above mentioned results differ from the findings reported in previous studies on teenagers from 8 Middle East and North African countries about parenting practices that revealed differences in parenting strategies for girls and boys (Dwairy et al., 2006). Also the findings of the current study were in agreement the results of an Egyptian study which found that involvement of parents among older children was the lowest level of parents' involvement (Dwairy and Menshar, 2006) .Current data suggest that parental involvement is linked with a decreased probability of victimization by peers. The association between parental involvement and peer victimization in Egypt was statistically significant (Table 3). This is consistent with the results from a previous study in China which reported that children with greater parental encouragement, emotional support and parent-child communication were less prone to be bullied (Peng et al., 2019). The degree to which parents are involved in the lives of their children and the type of parental involvement are also important (Harel-Fisch et al., 2011). Nevertheless, the findings of the present study differed from a Libyan study which stated that no statistically significant relation between parental participation and peer victimization (Abdirahman et al., 2013). Some of the differences between the countries can be explained by the different levels of urban growth, socio-political status and economic development. Previous North Africa and Middle East researches reported that wealthier, more urbanized communities have parenting styles that allow for greater independence of the child, which may explain why the current study findings showed significant association between parental involvement and peer victimization 
(Dwairy and Menshar, 2006).

Regarding teachers' perception about Bullying identification, intervention and prevention, the current study showed that more than one half of teachers $(56.6 \%)$ reported that they had not received or witnessed reports about bullying incidents in school during the last month ( Table 4 ). This disagreed with a study done by Thomas, 2017 on an analysis of teachers ' perceptions of bullying at the elementary school level which revealed that $62.5 \%$ of teachers had witnessed or experienced some type of school bullying and/or has had a bullying incident reported to them by a student or guardian.

Most of the teachers were able to identify bullying, $61.4 \%$ of them did not find it difficult to distinguish between bullying and playful teasing. This confirms with Olweus findings that the easiest type to detect is the visible bullying, and that the teachers are aware of this type of bullying (Olweus, 1993). Similarly, Williams and Lerner noted that teachers were able to recognize bullying from playful teasing, and explained that teasing happens between two children of equal power and that it is clear that these actions are only for fun with no physical or emotional violence (Williams and Lerner, 2019).

The current research work has shown that most teachers (97.6\%) believe that school plays an important role in minimizing bullying (Table 4). This shows that teachers understand the critical role school plays in the prevention of bullying. However, this finding differs from results of an interview with teachers who were questioned about the role of school in reducing bullying; they said that bullying is a bad behavior that parents at home must avoid and no role for school in reducing it (Rigby, 2020).

Almost all teachers (98.8\%) agreed that bullying can have a serious impact on children's development and a negative effect on students ' academic achievements (Table 4). This is in accordance with a study of 1,400 students in Australia which found that around a third of the students who had been bullied had difficulty in concentrating in classes because of their fear of bullying (Skrzypiec, 2008). Also a study done by Espelage (2015) showed that bullying victims can suffer from depression, anxiety, and low selfesteem which makes them avoid going to school, even bullying can lead to the student committing suicide. 
As for Bullying Intervention, 95.2\% of teachers in the present study agreed that female teachers are more reactive to bullying than male teachers (Table $4)$.

Along the same line; Kavanagh et al. (2018) reported that female teachers take bullying more seriously, and they also show more empathy than male teachers. Also, it is in parallel to a study done by Espelage (2015) who found that male teachers may ignore bullying more than female teachers, particularly the indirect type of bullying.

The current work showed that almost all the teachers (98.8\%) agreed that topics about bullying prevention should be part of the curriculum of elementary school. Because of the difficulty they mentioned about having heavy load of work and tight time, they might not always be ready to discuss bullying in the classroom except if it was included in the curriculum. This finding is similar with that of Zhang et al., 2019 in their study on bullying reporting concerns as a mediator between school climate and bullying victimization/aggression; who stated that one of the best preventive antibullying practices is incorporating the anti-bullying content in the curriculum and in the classroom.

Limitations: 1- The study was carried out in governmental schools only as it was difficult to conduct it in private schools.

2-The cross-sectional design limits our ability to conclude causal relationships and our analyses should be viewed as exploratory in the absence of longitudinal data.

Conclusion: Involvement of parents is associated with a decreased risk of victimization. Most teachers had misperceptions about identification of bullying and its parameters.

Recommendations: 1-Further systematic research is needed to obtain deeper understanding of bullying types, signs and implications of school bullying. 2-Develop a schoolbased bullying prevention program that can be adapted in the Egyptian culture and tackles bullying at various social levels including not only teachers, but also staff/administration, social workers, students and parents. 3-Improve teachers' knowledge about bullying through a training workshop that focuses on raising awareness of bullying identification, intervention, prevention, improving self-efficacy and learning stress management skills. 
4-Bullying prevention should be part of the curriculum of elementary school. 5- The three questions studied parent involvement have a combined effect on the student behavior so it is recommended to have a score system where individual scores are combined and the total score could be used for further studies.

\section{Conflict of interest}

The authors declare that they have no conflict of interest.

\section{Funding}

This research did not receive any specific grant from funding agencies in the public, commercial, or not-forprofit sectors.

\section{Acknowledgement}

The authors are thankful to the schools headmasters and teachers and all the study participants for their contribution in this research.

\section{References}

1. Abdirahman $\mathrm{H}$, Fleming $\mathrm{L}$ and Jacobsen $\mathrm{K}$ (2013): Parental involvement and bullying among middle school students in North Africa. East Mediterr Health J; 19(03): 227-33. https:// doi.org/10.26719/2013.19.3.227

2. Central Agency for Public Mobilization and Statistics (CAPMAS) (2018): Egypt in figures. Available at: http://www.sis.gov.eg/
Story/129692/Egypt-in-Figures-2018?lang=enus.

3. Dean AG, Sullivan KM and Soe MM (2013): Open Epi: open source epidemiologic statistics for public health. Available at: https://www. openepi.com/Menu/OE_Menu.htm

4. Dwairy M, Achoui M, Abouserie R, Farah A, Sakhleh A, et al. (2006): Parenting Styles in Arab Societies: A First Cross-Regional Research Study. J Cross-Cult Psychol; 37: 230.

5. Dwairy M and Menshar K (2006): Parenting style, individuation, and mental health of Egyptian adolescents. J Adolesc; 29(1): 103-17.

6. Espelage D (2015): Taking peer victimization research to the next level: Complex interactions among genes, teacher attitudes/behaviors, peer ecologies and classroom characteristics. J Abnorm Child Psychol; 43(1): 77-80.

7. Farahat NS (2019): An assessment of teachers' perceptions of bullying in an Egyptian school. Available at: URI: http://dar.aucegypt.edu/ handle/10526/5611

8. Fleming LC and Jacobsen KH (2010): Bullying among middle-school students in low and middle income countries. Health Promot Int; 25(1): 73-84. https://doi.org/10.1093/heapro/ dap046

9. Galal YS, Emadeldin M and Mwafy MA(2019): Prevalence and correlates of bullying and victimization among school students in rural Egypt. J Egypt Public Health Assoc; 94(1):18. https://doi.org/10.1186/s42506-019-0019-4

10. Garandeau C, Vartio A, Poskiparta E and Salmivalli C (2016): School bullies' intention to change behavior following teacher interventions: Effects of empathy arousal, condemning of bullying, and blaming of the perpetrator. Prev Sci; 17(8): 1034-43.

11. Global School-based Student Health Survey (GSHS) (2011): Purpose and methodology. Geneva, World Health Organization. Available at: http://www.who.int/chp/gshs/methodology. 
12. Haraldstad K, Kvarme LG, Christophersen KA and Helseth S (2019): Associations between self-efficacy, bullying and health-related quality of life in a school sample of adolescents: a crosssectional study. BMC Public Health; 19(1):757.

13. Harel-Fisch $\mathrm{Y}$, Walsh S, Fogel-Grinvald $\mathrm{H}$, Amitai G and Craig W (2011): Negative school perceptions and involvement in school bullying: A universal relationship across 40 countries. J Adolesc; 34(4): 639-52.

14. Hussein MH (2010): The Peer Interaction in Primary School Questionnaire: Testing for measurement equivalence and latent mean differences in bullying between gender in Egypt, Saudi Arabia and the USA. Soc Psychol Educ; 13(1): 57-76. https://doi.org/10.1007/ s11218-009-9098-y

15. Jungert T, Piroddi B and Thornberg R (2016): Early adolescents' motivations to defend victims in school bullying and their perceptions of student-teacher relationships: A selfdetermination theory approach. J Adolesc; 53: 75-90.

16. Kavanagh A, Priest N, Emerson E, Milner A and King T (2018): Gender, parental education, and experiences of bullying victimization by Australian adolescents with and without a disability. Child Care Health Dev; 44(2):33241.

17. Kazarian S and Ammar J (2013): School Bullying in the Arab World: A Review. AJP; 44(473): 1-18.

18. Kevorkian MM, Rodriguez A, Earnhardt M, Kennedy $\mathrm{T}$ and Borror J (2016): Bullying in elementary schools. J Child Adolesc Trauma; 9(4): 267-76.

19. Khafagy MA (2000): Prevalence of bullying behaviour and its association with health-related symptoms among preparatory school students in Mansoura city. Benha Med J; 17: 111-24.

20. Lester L, Pearce N, Waters S, Barnes A, Beatty $S$, et al. (2017): Family Involvement in a
Whole-School Bullying Intervention: Mothers' and Fathers' Communication and Influence with Children. J Child Fam Stud; 26(10): 2716-27.

21. Markkanen I, Välimaa R and Kannas L (2019): Forms of bullying and associations between school perceptions and being bullied among Finnish secondary school students aged 13 and 15. Int J Bullying Prev; 6:1-0. Available at: https://jyx.jyu.fi/handle/123456789/67378

22. Menesini E and Salmivalli C (2017): Bullying in schools: the state of knowledge and effective interventions. Psychol Health Med; 22(sup1):240-53.

23. Olweus D (1993): Bullying at school: What we know and what we can do. Malden, MA: Blackwell Publishing, 140 pp. Available at: https://doi.org/10.1002/pits.10114

24. Olweus D (1994): Bullying at school. Aggressive behavior. Springer, Boston pp. 97-130.

1. Available at: https://link.springer.com/cha pter/10.1007\%2F978-1-4757-9116-7_5

25. Peng K, Zhu X and Gillespie A (2019): Selfreported Rates of Abuse, Neglect, and Bullying Experienced by Transgender and GenderNonbinary Adolescents in China. JAMA; 2(9):e1911058.

26. Rigby K (2020): How teachers deal with cases of bullying at school: what victims say. Int J Environ Res; 17(7): 2338.

27. Sample size calculation (2017): Available at: http://web1.sph.emory.edu/users/cdckms/ samplesize $\% 20$ icc\%20deff2.html.

28. Skrzypiec G (2008): Living and Learning at School, document presented at the Annual Conference of the Australian Association for Research in Education. Available at: https:// www.researchgate.net/publication/228383467_ Living_and_Learning_at_School.

29. Thomas TW (2017): An Analysis of Teachers' Perceptions of Bullying at the Elementary School Level .This is to certify the doctoral 
study. Available at: https://scholarworks. waldenu.edu/cgi/viewcontent.cgi?referer $=\&$ ht tpsredir $=1 \&$ article $=5208 \&$ context $=$ dissertatio ns.

30. Williams PG and Lerner MA (2019): School Readiness. Pediatrics; 144(2): e20191766. doi:10.1542/peds.2019-1766

31. Zhang S, Mulhall PF, Flowers $\mathrm{N}$ and Lee NY (2019): Bullying reporting concerns as a mediator between school climate and bullying victimization/aggression. J Interpers Violence; 30(3): 283 - 96 